\title{
Liberation for straw dogs? Old materialism, new materialism and the challenge of an emancipatory posthumanism
}

\author{
Erika Cudworth \\ University of East London \\ Stephen Hobden \\ University of East London
}

\begin{abstract}
$\underline{\text { Abstract }}$
The term 'new materialism' has recently gained saliency as a descriptor for an eclectic range of positions that question the human centred and human exclusive focus of scholarship across the humanities and social sciences. In turn these emerging perspectives have been subject to critique by those writing in the established materialist tradition who argue that new materialism ignores the unique specificity of human agency and the transformatory capabilities of our species. Our previous interventions have endorsed a particular account of posthumanism that draws together complexity influenced systems theory with elements of political ecologism that have incorporated aspects of established materialist and humanist thinking. This article rejects the old materialist critique that denies the emancipatory potential of posthumanist thinking, and explores the potential for an emancipatory posthumanism.
\end{abstract}

$\underline{\text { Key words }}$

Complex systems, emancipation, new materialism, posthumanism

\section{Introduction}

In Tom Robbins' comic novel, Skinny Legs and All, a series of inanimate objects -- a sock, a can of beans, a silver spoon and two ancient and spiritually invested things, a painted stick (or self-described 'navigational instrument') and a conch shell -- find themselves brought together by events and destined to travel together from the 
American Midwest to Jerusalem. The reader should allay disbelief, cautions Robbins, because:

The inertia of objects is deceptive. The inanimate world appears static, 'dead' to humans only because of our neuromuscular chauvinism. We are so enamoured by our own activity range that...We regard the objects that polkadot our daily lives as if they were rigid, totally predictable solids, frozen inferiority in time and space. (Robbins, 1990, p. 62)

But lo and behold:

A gentle nudge from Conch Shell's spire punctured the bean can's musings. "We must depart now", Conch Shell said. "Painted Stick has taken his fix on the guide star. "

"Hey" yelled Dirty Sock. "Round 'em up and head 'em out!" He was certainly enjoying himself.

Spoon popped up tentatively over the gully edge. She was nervous but under control.

Very well, thought Can o' Beans. On to Jerusalem...

Under cover of darkness they scooted, toddled and bounced along... (Robbins, 1990, p. 63)

Of all the complicated interwoven narratives that make up the book, the travails of the internationally travelling objects are most hilarious. We think that some of the 'old' and some of the 'new' materialists discussed in this paper might also laugh at the antics of these plucky and determined things. They would do so, however, for different reasons. For new materialists, accounts of agency that are human centred and human exclusive fail to attend to the powers of the non-human world in making and remaking our shared world. Robbins, like theorists working within new materialism, is perfectly clear that shells and cans of pork and beans cannot speak as we humans do, but challenges us to imagine what they might have to say. Yet, there 
have been strong criticisms of such a position of distributed agency. If we humans are simply another node in the relational net of lively matter then how exactly can we be seen to act in and on the world, in particular, in the pursuit of human projects of emancipation? For old materialists, the laugh is that the contents of a comic novel and a book on political theory might show such striking resemblance.

We have recently made a call for a Posthuman International Relations. As such, our work has been associated with 'new materialism' (Chandler, 2013). It is worth noting that ideas about which ideas and positions might be 'posthumanist', and which might be 'new materialist' are often used interchangeably by many authors identifying with such positions, and also by their critics (see for example, Braidotti, 2013; Schmidt, 2013). Whilst we are not quite convinced that the overlap is as tight as some suggest, in this paper we examine some examples of posthumanist/new materialist positions and their challenge to humancentred notions of the political.

As Diana Coole and Samantha Frost suggest (2010: 1), in the light of the "massive materiality" that makes us up in our embodied condition as human animals - embedded in webs of dependencies and relations with myriad other species and forms of 'matter', produced and reproduced by social and economic structures that shape our everyday existences - how could we be anything other than 'materialists'?. The new materialist turn has also been given added impetus by the development of controversial political issues which involve the politics of matter such as climate change or applications of biotechnology. We see this broadening out of concern with the material as a positive move towards more inclusive and less parochial social science. Yet whilst we might concur with Coole and Frost that we are increasingly 'all' materialists now, they underplay the contention around the notion of the material.

For some, perhaps 'old materialists', the increasing influence of new materialism has been a matter for concern. In particular, the eclectic and often slippery perspectives that constitute new materialism have been seen to undermine the potency of older more established materialist positions, particularly those associated with Marxism. Here, we consider arguments that new materialism ignores the unique specificity of human agency and the transformatory capabilities of our species. Interestingly, for some advocates of posthumanism, and for some critics, the division between 'old' and 'new' materialism is dichotomous - it concerns ontological incompatibility. Criticisms of our own work have alluded to this and suggested that we are 'bolting on' complexity analysis to a normative political project that is decidedly humanist (for example, Edelmann, 2012). Our previous 
interventions have certainly endorsed a particular account of posthumanism that draws together complexity influenced systems theory with elements of political ecologism that have incorporated aspects of established materialist and humanist thinking. This article explores the potential for a number of political projects within a posthumanist frame. In doing so, we reject the old materialist critique that denies the emancipatory potential of posthumanist thinking; and question those positions in new materialism that tend towards biological determinism and which have been largely responsible for generating these critiques.

\section{Varieties of New Materialism and the Challenge to Humanist Politics}

At one level, the intellectual project of new materialism is to insist on a reconfiguring of our ideas about the social, economic and political as a result of developments in the natural sciences that have disturbed nineteenth century certainties about the nature of the material world (Coole and Frost, 2010: 5-7). This project is a broad and a contested one. In this section, we discuss the range of approaches in posthumanism/new materialism, but first, we begin by considering what might be common strands.

\section{'Ten Tenets of the New Materialism'}

While William Connolly (2013a, pp. 399-402) suggests that there are ten distinguishing features which unite the various very different new materialist approaches, we suggest that these can be grouped under three main headings.

First, the radical ontological claim of the new materialism is the priority given to matter. Matter, and in particular its self-organising capabilities becomes the centre of attention. This leads to a rejection of a mind and body distinction. All things, living and non-living, are constituted of the same basic elements. Connolly describes this ontological position as a 'protean monism'. Matter is therefore (drawing on complexity thinking) imbued with a dynamic quality which contains self-organising capacity, such that there is a tendency for ever more complex formations to appear. Matter is not seen as 'dead' but as containing energy-matter complexes which are constantly in flux.

A second area of concern relates to the implications of thinking within new materialism. Connolly advocates a 'speculative realism'. This rejects 
postmetaphysical approaches (that is, those demonstrating reflexivity in their use of Enlightenment categories such as 'reason') in favour of a 'contestable metaphysic and cosmology'. This stresses the dynamic character of matter such that an awareness is demonstrated of 'differential periods of stability, being and relative equilibrium in this or that zone while coming to terms with periods of real disequilibrium and becoming' (Connolly, 2013, p. 400, emphasis in original). This disjuncture between periods of stability and instability has epistemological issues which challenge traditional approaches for understanding human and non-human processes. As a result a 'problem orientation' is needed. Likewise the new materialism challenges human-centred ways of thinking. While humans may not be the centre of things, Connolly argues that they think more profoundly about their situation than other species. This, he argues, doesn't excuse humanity from thinking about its position in the context of a wider set of relations with the rest of nature, rather, it heightens this responsibility.

Third, the acknowledgement of the subjectivity of humanity in a world where the human isn't necessary prompts Connolly to advocate the development of an 'ethic of cultivation'. Such an ethic needs to be located both at the level of the individual and within institutions. Additionally our focus of attention needs to be wider than the local, which Connolly describes as 'the sufficiency of cultural internalism'. While the focus can't be everything, all of the time, there is a requirement to be aware of the embedded character of phenomena and the levels of analysis in which it is possible to investigate. Ultimately our concerns should be at the planetary level. Such a focus also prompts us to be aware that there may be things beyond our comprehension - and such issues, politics being one, oblige experimental action.

As noted, Connolly advocates a speculative realism. This is a philosophical realism as opposed to a political realism. And it is a realism of a very specific sort. While it maintains that there is a physical world of which we can have knowledge, it denies a separation between us as observers and material objects. The mind is an emergent feature of the body. It is speculative in the sense of acknowledging an awareness to the limits of our knowledge. This acknowledges a central unknowableness to existence related to the difficulties in understanding processes of self-organisation. Connolly (2013b, p. 77) argues that "we are beings flopping around in one corner of a cosmos that exceeds our capacity for knowledge, selfawareness, and mastery". As a result speculative realism "folds a fungible element of mystery into its philosophy" (Connolly 2013b, p. 9). 
Connolly is keen to emphasise the common underpinnings of new materialism and we concur with his 'ten tenets' as a useful definitional starting point. Yet these ten tenets have given rise to a plethora of positions, and these have marked differences. There is a spectrum of approaches to posthumanism that might be considered to be more or less critical in focus and give rise to rather different political projects. One of the reasons for this is that Connolly's ten tenets do not indicate the divergences between different ontological positions implied by the divergences in, for example, complexity thinking. As we have found, there is "no unified theory of complexity" (Bertuglia and Vaio, 2005, p. 315). The term can be used to describe a variety of theoretical positions which draw upon a similar conceptual lexicon while having radically different epistemological and ontological perspectives. Elsewhere we have identified four different ways in which complexity theory has been applied in the social sciences (Cudworth and Hobden, 2009).

Our own engagement with complexity has been general and philosophical, and built around three interdependent concepts we have found particularly useful: complex adaptive systems, self-organisation and emergence (see Cudworth and Hobden, 2011). Our selection of these concepts has a number of motivations which have led us to develop a particular perspective within new materialism. While Connolly uses complexity in a reinvention of pluralism, we use it to very different ends. There is then, we suggest, a plurality of posthumanisms, some of which, we will now explore.

\section{Varieties of posthumanist political theory}

The term posthumanism has been understood in a variety of different ways (Wolfe, 2010, p.xi). In line with Connolly's 'ten tenets' however, a clear common theme in posthumanist scholarship would be to say that it represents a reaction against the view of human exceptionalism (or anthropocentrism). This view understands humanity to be marked off from the huge diversity of non-human animal life due to 'exceptional characteristics', such as the possession of syntactical language or of 'free will'.

One strand of new materialism/posthumanism might be referred to as 'new vitalism'. The latter has been particularly associated with the influence of Gilles Deleuze, who did not consider himself a materialist but rather, was concerned that his work be understood as vitalist (Coole and Frost, 2010: 9). In political work, this 
position is best illustrated by the 'enchanted' or 'vital' materialism of Jane Bennett (2010) who argues that inorganic matter such as kerbside litter (trash) or an electricity grid, all exhibit force and vitality rendering them active, productive and self-creating. Bennett argues for a vital materialism in order to recognize the role of apparently inanimate matter affecting and configuring situations and events. In vital materialism there is a tendency to minimize the differences between subjects and objects with this notion of a vitality which runs through both human and nonhuman matter. The end in view is the development of a more environmentally aware and cautious politics, but the elevation of the "shared materiality of all things" does seem to be a rather blunt instrument in securing this end. Bennett's notion of 'thing power' understands agentic capacity as distributed, apparently equally, “across a range of ontological types." (2004: 347-72).

There are difficulties here both of conceptual conflation and lack of clarity. For Bennett, non-human assemblages can act. However, what she actually seems to mean is that assemblages can have an impact or effect on humans and non-humans. Here, Bennett is conflating the idea of the properties and powers of beings and things, and the notion of action and the idea of agency, and there are serious questions to be raised about her assumption that a distributed concept of agency will be effective in unsettling humancentric politics (Bennett, 2010, p.13).

The second approach, hybridization, is best illustrated by the contributions of Bruno Latour, for whom the social world is an assembly of material entities and processes which is constituted through the interactions of all kinds of matter (human and non-human) in the form of networks. Latour (1993) describes the emergence of apparently modern Western societies through the interaction of two processes purification and hybridization. The processes of purification involve the separation of the human world from the world of things and the construction of the world of nature and its scientific study; separate from the study of the social world with its selves, cultures and politics. Yet, Latour argues, the human social world has never been pure, despite all the attempts to extricate it from the world of nature. However 'modern' we think we are, our world is one of relative degrees of hybridization as we are caught in networks of interactions and relations between what Latour would understand as more or less natural and more or less social phenomena. Within these networks, non-human matter can be understood as 'actant'. This is both a counter to humancentric prejudice, and reflects our reality as one of the multitude of species situated in a range of 'attachments' on planet earth (Latour, 2009, pp. 72-84). 
Latour's Actor Network Theory (ANT) holds that agency may be attributed to any object or 'actant', temporarily constituted by the emergent web of "materially heterogeneous relations" (Law, 2009, p.71). Here, as with the vital materialist position, agency is inflated conceptually (so that it becomes simply a capacity for action) and extensively (so that anything that has an effect on something else is seen as an actant, from fishermen to scallops). However, the difficulty with Latour is that in his broad sweep, all agency is understood as of the same quality. In addition, it is a property of 'things' rather than, as complexity thinking suggests, of systems in relation. Like Latour, we want to be able to discuss the ways that all kinds of creatures, beings and things, bound up in relations of complex systems and relations with their system environments, and are agential in the sense that they might "make a difference in the world" (Giddens, 1984). Both Latour and Bennett can be seen as subscribing to a position of agential realism. Here, the agency of matter, distributed across the world of 'being' makes up the beings, things and relations of which our world is composed. In both hybridity and vitalism, there is a tendency to horizontalism - relations are not understood to exist in a context of hierarchies of power. The flat, non-hierarchical networks for ANT cannot deal with power because it cannot make distinctions between nature and society, or between humans, other animals, plants and objects. In theorizing power, we consider that need such distinction between different kinds of being and objects in the world in order to recognise, for example that distinction such as those between humans and all other 'animals' are forged through and continue to carry, relations of inequality and domination. It is this flattening of social relations which old materialists find so objectionable in new materialist approaches.

Our own complexity engagements have led us down a very different route wherein we have been interested in the relations between stability and change, and the resilience of complex systems. We have remained committed to many of the insights of the varieties of political ecologism and have advanced a notion of 'complex ecologism' in trying to understand the current social formations of what, after Haraway, we would call 'naturecultures'. This uses complexity theory with its notions of co-existing, interrelated, multi-levelled systems to capture the ontological depth of relational systems of social domination (of colonialism, capitalism, patriarchy and so on) and their intersections. Complex ecologism assumes the coconstitution and co-evolution of social and natural systems in dynamic configurations (Cudworth and Hobden, 2011: 110-139). Whilst we have acknowledged that human communities of all kinds live in relations of dependency and reciprocity within complex natural/social systems with non-human beings, 
things and processes, we have stressed the domination of non-human nature under certain kinds of relations and the ways in which certain groups of relatively privileged humans are able to assert domination over certain other kinds of human, other animal and life forms.

Drawing on Margaret Archer's (2000) discussions of primary and corporate agency, and on Nickie Charles and Bob Carter's use of Archer's work (Carter and Charles, 2011), we have developed a three-fold approach to thinking about structure and agency that allows us to think about agency beyond the human (Cudworth and Hobden, 2013). First, reproductive agency acknowledges the way in which agential beings, both human and non-human, emerge into a pre-existent web of social relations and unequally distributed power and resources and their practices over time reproduce those situational constraints with relatively minor alterations. Second, there is transformative agency where humans and possibly some other creatures engage in a struggle over resources and social organization to effect differences in that distribution. The human world overlaps with innumerable nonhuman systems, both animate and inanimate, which can impact and influence, and indeed radically change the structures of the human world. We describe this as 'affective agency'. As we will later see, some consider an understanding of our embedding in 'natural' systems as subjecting humanity to the rule of blind necessity. This is reflected in some posthumanist work. The title for John Gray's controversial Straw Dogs comes from the Tao Te Ching, wherein "Heaven and Earth are ruthless and treat the myriad creatures as straw dogs" to be trampled on and destroyed similarly to the straw effigies offered to the gods in ancient Chinese rituals (Gray, 2002, p. 33-34). We would concur with Gray that exclusive humanism is arrogant and ignores our shared vulnerability with other creatures, but do not think that humans are 'straw dogs'. Rather, we consider the agency of non-human species to be constricted in the extreme and that privileged groups of humans exercise considerable power over the lives of human and non-human animals and intervene dramatically and often disastrously in non-human lifeworlds.

We have argued for a conception of differentiated agency in which the agential being of non-human animals, particularly mammals is countenanced, and the possibilities for agency very much depends on the relational systems which produce such being. We would use affective agency to discuss the significant effects of natural systems and the beings and things caught up in them and in their relations with other systems. This is not simply the causal powers of a being or thing but a systemic impact that is collective and significant. By significant, we mean that it 
'makes a difference in the world', that it alters the systemic conditions, the agential landscape, for other beings and things. The impact of global warming, or the effects of a viral pandemic would be examples here. Whereas hybridity and vital materialism consider agency simply to be a quality of material existence, our conception of agency incorporates the idea that non-human life and non-human animals are social actors able to exercise agency without seeing agency simply as a capacity that material beings can exercise. We need a situated and differentiated notion of agency that understands the ability of creatures and things to 'make a difference in the world' as a question of situated relations rather than intrinsic capacity alone.

These discussions of theorizing the social, and potentially political, agency of beyond-human life have posed a challenge to politics-as-usual. Perhaps not unsurprisingly, the challenge has been resisted and it is in our view most unfortunate that some critics seem set on constituting a dichotomy rather than a continuum of positions on 'the material' and in straight-jacketing certain perspectives to either a politics of stasis, one of neo-liberalism or one of emancipation.

\section{Resisting the Challenge to Humanist Politics}

There are some very set against the challenge of 'new' materialism. In many cases, these appear to be 'old' materialists disturbed by the apparent uncertainty implied by post-materialist analyses. As Connolly suggests, this lies in a partial reading of the range of new materialism(s):

A philosophy of becoming set on several tiers of temporality does not, though some fools project such a conclusion into it, postulate a world in which everything is always in radical flux. That would mean that you could never act upon one desire before it was replaced by another. The projection of such a judgement into the new materialism means that the projector has so far only heard one part of the thesis being advanced. (Connolly, 2013a, p.401)

However, this track has been the chosen route of critique. New materialists, David Chandler argues, celebrate human embeddedness in the non-human world. Their 
perspective is to engage with an ethics of becoming, where knowledge can only illuminate what is happening rather than predict what is to come. This, for Chandler (2013a, p. 527) is "far too high" a price to pay, and one for which "the prize on offer is a false one". The reason for this, Chandler (2013a, p. 528) argues, is because it removes our subjectivity as human beings; "we can never be human subjects, collectively understanding, constituting and transforming our world". New materialist approaches suggest that we live in a world of becoming, where it is the connections and inter-relations that take priority, as a result the ontological focus is "objects transforming objects - rather than subjects transforming objects" (2013a, p. $529)$.

There are two interrelated implications Chandler highlights. First is that we are subject to the "rule of blind necessity", where our options become those of a micro politics, the transformation of the self as a more ecologically aware embedded being. Second, and most importantly, this move, Chandler claims, puts us beyond the world of the knowable. Drawing on Hannah Arendt, who argued that the world that could be understandable marks the limits of what we should consider, he argues that the unpredictability implied by New Materialism leads to "a desert", and as such removes "the meaningfulness of the world itself" (Chandler 2013a, p. 534). When we lose the possibility of engaging meaningfully in the world "we lose the freedom of the goal-determining subject" (Chandler, 2013b, p. 18). In a world where the predictability of our actions is limited we become incapable of action (Chandler, 2013a, p. 525). Human freedom is only possible through the overcoming of necessity, and for this, Chandler (2013b, p. 6) argues we need fixed understandings: "it is through these fixed structures of meaning that we understand ourselves as able to master necessity - the relations of cause and effect".

If only our political intentions were so straightforwardly realisable in their outcomes! Surely, even if one has never chanced upon any of the ideas of complexity theory, new materialism, posthumanism and the like, the simple point that political ends are often at odds with the intentions of actors has become abundantly clear in the impact of radical politics in the last century, whatever the quality of the understandings of the world on which political interventions were founded. It is interesting that Chandler endorses Lenin's engagement with questions of freedom and necessity somewhat approvingly. The outcomes of the Russian Revolution of October 1917 are well-debated, but the notion that the revolution was in many aspects 'betrayed' by consequent developments is now widely accepted - albeit that Emma Goldman's contemporary observations were harshly received: 
Try as I might I could find nowhere any evidence of benefits received either by the workers or the peasants from the Bolshevik régime.

On the other hand, I did find the revolutionary faith of the people broken, the spirit of solidarity crushed, the meaning of comradeship and mutual helpfulness distorted. (Goldman, 1923, p.8)

That the outcomes of our actions may be different from our intentions, or in Morin's (2008, p. 96) terms that "action escapes the will of the actor," is far from a novel idea. Yet while complexity thinking has often focussed on the problems confronting policy makers (Forrester, 1971), there is a developing literature on policy making under conditions of complexity. Sandra Mitchell (2009), for example, suggests replacing traditional 'predict' and 'act' policies with processes of scenario evaluation and 'adaptive management'. In a similar vein, Robert Axelrod and Michael Cohen (1999) argue that not only is it possible to make policy under conditions of complexity, complexity itself can be actively harnessed in pursuit of goals. While the analysis of policy making, and the development of policy making when confronted by complexity is a recent development, the point is that this would be a rejection of the idea that in complexity we confront a situation of 'blind necessity'.

Chandler's claim is that the "rule of blind necessity" prescribes our options in terms of a micro politics. This, he suggests, involves the transformation of the self into a more ecologically aware embedded being. This individualist response to ecological crises is certainly present in the literature on political ecology, associated particularly with the work of Arne Naess (1979) and Warwick Fox (1995) but has been effectively critiqued by left and feminist political ecologisms (for example, Gorz, 1994; Soper, 1996). Part of the problem is the narrow selection of new materialists on which Chandler focuses his attention (Bennett, Connolly and Latour). In addition, he over-compares the similarities between approaches and the political projects they advance. Whilst his arguments about a politics of being and stasis might work for Bennett, they do not work so well for Latour, for example. Schmidt (2013: 177-78) makes no distinction at all between the "general positions and assumptions" of the wider range of posthumanist positions she references. 
A better example for Chandler's argument for posthumanism as a politics of being-in-the-world in face of ecotastrophe would be John Gray, who, following Lovelock and his ilk, considers that the current impact of humanity on patterns of change in natural systems, means that we might be simply tossed aside as a species unfit for purpose in the earth system. Gray (2002) smirks at the demise of arrogant humankind, and the flawed humanist political projects we insist on holding onto; dismissing what we would call critical posthumanism as 'green humanism' that reflects the same naïve doctrine of the possibilities for human salvation. For Gray, we, along with Schmidt and Chandler, are like poor deluded and despairing Nietzsche, "trapped in the chalk circle of Christian hope" (Gray, 2002, p. 48). Gray however, is not quite the secularist he often considers himself to be. More recently, and drawing on non-Western political thought, Gray (2013) suggests that we might address our arrogant humancentredness by learning silence and the art of simply 'being'. This, certainly, is a recommendation for doing nothing in the face of potential calamity.

Chandler suggests that such a politics of stasis is the outcome of new materialism and an intrinsic element of a posthumanist position. But it is not. There are as many political paths for posthumanisms as for the humanisms of modernity. This is something that neither Chandler nor Schmidt can acknowledge, for it is on a homogenous new materialism that any argument rests. Both the politics of humanism and of posthumanism can be deployed for liberal, left and other forms of political project. For neither Latour, nor Connolly, nor those with more radical perspectives (feminist or de-development, or indeed, our own), accept that creatures are straw dogs. We are all acutely aware however, of the 'fragility' of human and non-human lifeworlds, it is this shared vulnerability of the living which is the grounds of separation from the humancentric modernism of Chandler, Schmidt, Lenin and Francis Fukyama! Schmidt (2013) is obviously hostile to environmental politics, using some ideas about climate change policy (drawn entirely from liberal international institutions) "in dialogue" with new materialism in order to assert that the epistemological underpinnings of the latter make it possible for it to "become aligned" with neo-liberal international governance. The ontology of modernity and the certainties of realist or positivist epistemologies led to a range of contested pathways towards very different futures. The future may be less certain for new materialisms but the notion of desirable change is still as deeply contested, and what might be done is not easily read-off from a new materialist and posthumanist analysis in the way which Schmidt suggests, but depends on what kind of posthumanist position we are speaking of. 


\section{Some Posthumanist Political Projects}

The posthumanist critique raises vital questions for human being in the world and demands qualitative and quantitative shifts "in our thinking about what exactly is the basic unit of common reference for our species, our polity and our relationship to the other inhabitants of this planet" (Braidotti, 2013, p.2). While we might endorse Rosi Braidotti's sentiments, it needs to be acknowledged that both the analyses emerging within posthumanism/new materialism and the political projects these positions imply or endorse cover a range of political positions.

\section{A conservative politics of attachments}

For Latour (2005), a huge, unknowable multiplicity of realities exists. Each actor has their own 'world' and this provides the source of agency and their inspiration for action. In turn, Latour is sceptical of political claims for the existence of overarching systemic relations of power and inequality around which emancipatory politics has coalesced.

Latour's most obvious attack on emancipatory politics is contained in his 2004 paper on the problems of critique within science and technology studies. Here, he suggests that around ninety per cent of social critique fall into two approaches "the fact position and the fairy position" (2004a, p. 237). The fact position holds that 'objects of belief' are merely concepts onto which power is projected; while the fairy position argues that individuals are dominated by external forces (such the operation of capitalism or of gender relations) that may by covertly effective without the awareness of those whose behaviour is affected (2004a, p. 238). In the latter, critique is straightforward, and any evidence which might contract a theoretical certainly is explained away by unseen forces so that "You're always right!" (2004a, p. 239). While both positions have their attendant difficulties, it is the 'fairy' position which seems most irksome to Latour.

We require a new way of conceptualising 'nature'. Nature is not an obvious domain of reality, and we have a false dichotomy between the nonhuman and human that needs to be reassembled (Latour, 2004b). In doing this, we need to constitute a political community incorporating humans and non-humans and building on the experiences of the sciences as they are practiced. Moving beyond the 
modernist institutions of 'mononaturalism' and 'multiculturalism', Latour develops the idea of 'multilateralism'. This is Latour's notion of the 'good life', one which in an interview he described as "the composition of a common world" (Latour and Navaran, 2011). Latour has more recently moved away from issues of representation and deliberation to political culture and in particular, seeing if traditional ways of seeing the world might shed light on and add legitimacy to arguments for a nonmodern posthuman politics. Latour has invoked a more traditional conservatism drawing on ideas about 'respect for creation' within the Orthodox Christian tradition of Central and Eastern Europe (Latour and Naravane, 2011). For Latour, the threat of environmental collapse is strong, and engendering public emotion is necessary to secure the political consideration of our attachments to the nonhuman lifeworld and thereby secure ourselves. This return to religion however seems a retreat to a cultural politics of engendering ecological selves. Rejuvenating declining cultural mores to invigorate concern about the more-than-human world would appear to be a project doomed from the start.

\section{Complex pluralism}

William Connolly echoes in some ways, the earlier project of Latour - using new materialism as a frame within which to recast a liberal pluralist political project. Here, he is very much attuned to the concern of political alienation highlighted by Schmidt and Chandler. For Connolly (2013b, pp. 181-2), the desire to abandon electoral politics is understandable given how dysfunctional it is - yet deserting democratic means leaves the field to the right who consistently attempt to depict politics as a dysfunctional realm. Hence while forsaking democracy for Connolly is not an option, at the same time, working within democratic systems as currently constituted only allows limited possibilities for change.

The resolution to this conundrum lies, Connolly (2103b, p. 182) argues in a politics of 'micro-experimentation on several fronts'. Here he is advocating the possibilities that aggregated small changes to behaviour can result in large political changes. When role behaviour conforms to expectations this can act to legitimise current sets of arrangements, whilst 'large-scale role experimentations can make a difference on their own and help to set preconditions for constituency participation in more robust political movements' (Connolly, 2013b p. 184, emphasis in original). It is the cumulative power of such role experimentation and challenges to the existing order that is significant in creating a 'pluralist assemblage'. At critical moments, such as 
political disorder or economic chaos movements appear which reveal further the cracks within the existing order - promoting yet further role experimentation.

We can see clear overlaps with Latour's liberal project here, although these pluralist assemblages appear more open to the influence of social movement activity and the engagement of extra-parliamentary pressure in policy fora. In thinking about the presence of cracks in political order and the insertion of scientific (and other) expertise, these ideas could be linked to (neo)liberal forms of environmental governance. This is not to be associated with new materialism (as per Schmidt) but with liberalism. Current policy initiatives reflect the concerns of complex pluralism as articulated by Connolly. For example, in the UK the creation of what might be seen as a 'new' posthuman political settlement has been advocated by Nicholas Stern (2009). Stern's argument for a new 'global deal' via which we move to a carbon neutral economy can be read as a reflection of neo-liberal governance, guided by common-sense principles of effectiveness, efficiency and fairness, and an overarching framework of the 'greening' of the capitalist system and the liberal state. At the heart of his work is the simple calculation that, if the science of climate change is right, the cost of doing nothing about global warming would be very high, while the cost of transforming our energy system would be relatively low. Stern's policy measures are a series of corrections to market failures and externalities by using regulations to encourage market mechanisms to reduce emissions.

The 'greening of capitalism' is Stern's project, perhaps shared by Connolly. Even these ideas of low-carbon development and re-invigoration of democracy for ends both human and beyond represent however, not the cultivation of the environmental self, but a re-orientation of public policy. They do not represent the incapacity of politics. Other posthumanist positions lend themselves to progressive political projects outside the liberal frame. Here, it has been suggested that exploitative and oppressive relations exist and must be taken seriously, and that their challenge has seen the emergence of a post-humanist polities allied to the politics of emancipation, albeit one which stresses the notion that 'freedom' is both embodied and embedded.

\section{Critical Posthumanism}

We would define critical posthumanism as approaches to more-than-human politics which draw on aspects of critical theory and thereby contain an agenda for 
transformation. In developing a politics of emancipation however, it is important to remember that much radical politics of liberation draws very heavily on the same European Enlightenment humanism which informed a model of political and cultural universalism that has had disastrous consequences for many peoples and non-human lifeworlds. But does a problematizing of the liberal and Enlightenment foundations of emancipatory agendas mean that they cannot be disentangled from the imperialist mission of Western civilization? Does a new materialism involve the rejection of any kind of emancipatory agenda as Chandler and Schmidt suggest?

Many of us working within the posthumanist critique wish to advance an agenda which opposes the domination of life in all its variety. Yet as emancipatory politics has learned to its cost, there are many dangers in universalist schemas of all kinds and conceptions of liberty, rights, wellbeing and so on are fraught with contradiction. This is why in our own work, we have emphasised the importance of social intersectionality as an analytic frame. Our use of posthumanism is to indicate the understanding of 'humanity' as embedded in networks of relations of dependency with the non-human lifeworld, to emphasise the fragility of embodied life. In addition, we want to emphasise the importance of a posthumanist lens in examining phenomena which, in international politics, are often seen as exclusively human such as the practice of war, the delivery of welfare and security, the distribution of resources and so on. Humanism might sensibly appreciate the qualities of the human animal, but we would hope it might radically consider the extent to which these are entirely unique given the multiplicity of species. A critical humanism must also abandon its history of humancentrism and be highly attuned to the domination of the animal that is not human, in addition to the animal which is.

Work in the areas of de-development and eco-feminism provide a starting point for our own perspective. From a de-development perspective, such as advocated by Wolfgang Sachs (2008a, 2008b), there is a need to completely re-think forms of social organisation. For Sachs (1992) the notion of development "stands like a ruin in the intellectual landscape". In its place there is a need for a radically different path, particularly in the wealthier parts of the world. This way of life requires a prioritisation of the carrying capacity of the planet, and the envisioning of lifestyles within that capacity. Val Plumwood shares Sachs' concerns with the impacts of development on the planet and its capacity to support life. In terms of our relationship with the rest of nature her view is that notions of human domination over nature "must end either with the death of the other on whom he relies, and therefore with his own death, or with the abandonment of mastery, his failure and 
transformation" (Plumwood, 1993, p. 196). While Sachs advocates a de-development agenda, Plumwood argues for a reconsideration of our place within the rest of nature. Drawing on the political frameworks of indigenous Australian and North American cultures she argues for a non-colonial posthuman politics which develops a culture of belonging and community (as opposed to a prioritisation of conquest and private property), and on flourishing (to replace a western obsession with wealth). For Plumwood, a posthuman politics is not some form of pre-modern exchange with the modern, but rather, a re-working of elements of humanist politics of emancipation alongside non-Western and non-capitalist conceptions (Plumwood, 2002; also Salleh, 1997).

Paraphrasing probably the most quoted sentiment in International Relations, Ken Booth (2011, p. 329) has described Critical Theory as 'for the potential community of mankind and for the purpose of emancipation'. A critical posthumanism, we would suggest is for all that lives, and for the purpose of eliminating multiple forms of oppression. How might this be considered part of an emancipatory programme?

First it provides a form of analysis which stresses the common constitution of all living things. A systems analysis derived from complexity theory allows for the analysis of the interactions between human and non-human systems and between animate and in-animate systems. This forms the basis of an ethic of care and responsibility which does not cease at the species border. One of the central contributions of posthumanist work has been to question the character of these boundaries, and in particular to raise questions about those features which humans have declared indicate their uniqueness, such as tool use, or use of language. The intention here is to de-centre the position of the human. This is not to deny the planetary significance of human activity, but to indicate that many other species also possess capabilities once thought the sole preserve of humans.

While we don't regard our particular position to be one directed towards policy making, the implications of thinking about our actions are part of the emancipatory programme. In particular in thinking about policy issues we have suggested that a precautionary principle should dominate, a greater humility in terms of our embeddedness in non-human nature, and a priority towards the building of resilience within systems rather than the undermining of resilience. Both the de-development literature and the eco-feminist literature alluded to above indicate a requirement for a total re-constitution of our economic and social 
arrangements. This is a view with which we would concur. Intra-human and interspecies forms of domination are exacerbated by the capitalist systems and a more equitable form of social system could be a significant move towards alleviating both of these. How such a transition would be achieved is more problematic, and the posthuman perspective would not envisage a programmatic overthrow of capitalism, but rather change through small actions particularly as a result of increased awareness about forms of intra and inter-species domination. In this sense we see the posthuman move as being at home within the discipline of International Relations - which is a discipline which takes change at a global level as a central concern, though which to-date, in our opinion has been weak in terms of its contribution to understanding global environmental issues.

\section{Conclusion}

This article refutes the claim that in a complex world we confront blind necessity and that in acknowledging complexity we are incapacitated from moving towards a more just and equitable world. Certainly one conclusion that can be drawn from complexity is that any action is futile because we confront a situation of radical unpredictability. Indeed, this would appear to be the standpoint of John Gray who would see human attempts to improve their position as misguided. However that is not the only conclusion, rather, there is a growing body of literature on policymaking under complexity as well as some radical ideas for the re-invention of our world. Without a doubt it would be easier to make progress in a world where there was a predictable link between our actions and their outcomes. Yet, we argue, it is better to try to learn with complexity than to pretend that it is not there.

The claim that we exist in a condition of complexity is an ontological one, not an ethical one. However, an ethical position can be derived from a starting point in complexity. Complexity points to the overlapping and inter-connected character of human and non-human systems. This, we suggest, indicates the embedded character of human activity. Humans are not the independent separated beings of some religious and humanist claims. Furthermore an embeddedness in the rest of nature implies a need not only to prioritise our relations to the rest of nature, but also of our common origins with the rest of non-human nature. While it may be in human selfinterest to protect the rest of non-human nature, our shared heritage with the rest of lively matter points to a responsibility to minimise forms of oppression with the other forms of life on the planet. In most posthuman perspectives, creatures share 
vulnerabilities but they are not 'straw dogs'. For critical posthumanism there can also be emancipation and indeed, this is its ethical project.

\section{References}

Archer, M. (2000). Being human: The problem of agency. Cambridge, Cambridge University Press.

Axelrod, R. M., and Cohen, M. D. (1999). Harnessing complexity: Organizational implications of a scientific frontier. New York: Free Press.

Barad, K. (2003). Posthumanist performativity: Toward an understanding of how matter comes to matter. Signs: Journal of Women in Culture and Society 28, 801-831.

Bennett, J. (2004). The force of things. Political Theory 32, 347-72.

Bennett, J. (2010). Vibrant matter: A political ecology of things. Durham, NC: Duke University Press.

Bertuglia, C. S., and Vaio, F. (2005). Nonlinearity, chaos E complexity: The dynamics of natural and social systems. Oxford: Oxford University Press.

Braidotti, R. (2013). The posthuman. Cambridge: Polity.

Bunge, M. (2010). Matter and mind: A philosophical inquiry. Dordrecht: Springer.

Booth, K. (2011). Realism and world politics. London: Routledge.

Callon, M. (1986). Some elements of a sociology of translation: Domestication of the scallops and the fishermen of St Brieue Bay. In J. Law (Ed.), Power, action and belief: A new sociology of knowledge? (pp. 196-233). London: Routledge and Kegan Paul, 1986.

Carter, B., \& Charles, N. (2011). Human-animal connections: An introduction. In B. Carter \& N. Charles (Eds.), Human and other animals: Critical perspectives (pp. 1-30). Basingstoke: Palgrave.

Chandler, D. (2013a). The world of attachment? The post-humanist challenge to freedom and necessity. Millennium, 41, 516-534.

Chandler, D. (2013b). Freedom versus necessity in international relations: Human-centred approaches to security and development. London: Zed. 
Connolly, W. (2013a). The "new materialism" and the fragility of things. Millennium, $41,399-412$.

Connolly, W. (2013b). The fragility of things: Self organizing processes, neoliberal fantasies, and democratic activism. Durham, NC: Duke University Press.

Coole, D. \& Frost, S. (2010). New materialisms: Ontology, agency, and politics. Durham, NC: Duke University Press.

Cudworth, E. \& Hobden, S. (2009) 'Complexity Theory in the Social Sciences', The International Journal of Interdisciplinary Social Sciences 4, 4: 59-69.

Cudworth, E. \& Hobden, S. (2010) 'Anarchy and Anarchism: Towards a Theory of Complex International Systems' Millennium: Journal of International Studies, 39, 2: 399-416.

Cudworth, E. \& Hobden, S. (2011) Posthuman International Relations: Complexity, Ecologism and Global Politics, London: Zed Books.

Cudworth, E. \& Hobden, S. (2013) 'Of Parts and Wholes: International Relations Beyond the Human' Millennium Journal of International Studies, 42, 3 : 430-450.

Edelmann, F. (2012). Complex social system thinking beyond posthumanism: The exclusion of subjectivity and possibilities for human agency. Paper presented the Millennium Annual Conference, Materialism in World Politics, London.

Forrester, J. W. (1971). Counterintuitive behavior of social systems. Technology Review, 73, 52-68.

Fox, W. (1995). Towards Transpersonal Ecology. Dartington: Green Books.

Giddens, A. (1984). The constitution of society. Cambridge: Cambridge University Press.

Goldman, E. (1923). Preface to the first volume of the American edition of $M y$ Disillusionment in Russia. New York: Doubleday, Page and Co.

Gorz, A. (1994) Capitalism, Socialism, Ecology. London: Verso.

Gray, J. (2002). Straw dogs: Thoughts on humans and other animals. London: Granta. Gray, J. (2013). The silence of animals: On progress and other modern myths. London: Allen Lane. 
Habermas, J. (1996). Three normative models of democracy. In S. Benhabib (Ed.), Democracy and difference: Contesting the boundaries of the political (pp. 21-30). New York, NY: Columbia University Press.

Haraway, D. J. (1985). Manifesto for cyborgs: Science, technology, and socialist feminism in the 1980s. Socialist Review 80, 65-108.

Haraway, D. J. (2003). The companion species manifesto: Dogs, people and significant otherness. Chicago, Il. Prickly Paradigm Press.

Haraway, D. J. (2008). When species meet. Minneapolis MN: University of Minnesota Press.

Kauffman, S. (1993). The origins of order: Self organization and selection in evolution. Oxford: Oxford University Press.

Latour, B. (1993). We Have Never Been Modern. Hemel Hempstead: Harvester Wheatsheaf.

Latour, B.. (2004a). Why has critique run out of steam? From matters of fact to matters of concern. Critical Inquiry, 30, 225-248.

Latour, P. (2004b). The politics of nature: How to bring the sciences into democracy. (C. Porter Trans.). Cambridge, MA: Harvard University Press.

Latour, B. (2005a). Reassembling the social: An introduction to actor-network theory. Oxford: Oxford University Press.

Latour, B. (2005b). From realpolitik to dingpolitik or how to make things public. In B. Latour \& P. Weibel (Eds.), Making Things Public (pp. 14-43). Cambridge, MA: MIT Press.

Latour, B. (2009). A plea for earthly sciences. In J. Burnett, S. Jeffers \& G. Thomas (Eds.), New social connections: Sociology's subjects and objects (pp. 72-84). Basingstoke: Palgrave.

Latour, B. \& Naravane, V. (2011, January 4). I would define politics as the composition of a common world, interview with Bruno Latour, The Hindu. Retrieved from http://www.thehindu.com.

Law, J. (2009). Practising nature and culture: An essay for Ted Benton. In S. Moog and R. Stones (Eds.), Nature, social relations and human needs: Essays in honour of Ted Benton (pp. 65-79). Basingstoke: Palgrave Macmillan. 
Linklater, A. (1998). The transformation of political community: Ethical foundations of the post-Westphalian order. Oxford: Polity.

Linklater, A. (2005). Dialogic politics and the civilising process. Review of International Studies, 31, 141-154.

Morin, E. (2008). On complexity. Cresskill NJ: Hampton Press.

Mitchell, S. D. (2009). Unsimple truths: Science, complexity and policy. Chicago, IL: University of Chicago Press.

Naess, A. (1979) Self-Realization in Mixed Communities of Humans, Bears, Sheep and Wolves, Inquiry, 16, 95-100.

Plumwood, V. (1993). Feminism and the mastery of nature. London: Routledge.

Plumwood, V. (2002) Environmental culture: the ecological crises of reason. London: Routledge.

Robbins, T. (1991). Skinny legs and all. London: Bantam.

Sachs, W. (1992). Development: a guide to the ruins. New Internationalist. Retrieved from http://newint.org.

Sachs, W. (2008a). Zukunftsfähiges Deutschland in einer globalisierten welt (Sustainable Germany in a globalized world) Frankfurt: Brot für die Welt, eed and BUND - Fischer.

Sachs, W. (2008b). Climate change and human rights. Development, 51, 332-337.

Salleh, A. (1997) Ecofeminism as politics: Nature, Marx and the postmodern. London: Zed.

Schmidt, J. (2013) The empirical falsity of the human subject: new materialism, climate change and the shared critique. Resilience: International policies, practices and discourses, 1, 174-192.

Soper, K. (1996) Feminism, ecosocialism and the conceptualisation of nature. In The Greening of Marxism ed. T. Benton. London: Guilford Press.

Stern, N. (2009). The global deal. New York: Public Affairs.

Ulanowicz, R. E. (2007). Ecology: A dialogue between the quick and the dead. In F. Capra, A. Juarrero \& P. Sotolongo (Eds.) Reframing complexity: Perspectives from north and south (pp. 27-46). Mansfield MA: ISCE Publishing. 
Westley, F. et al. (2002). Why systems of people and nature are not just social and ecological systems. In L. H. Gunderson \& C. S. Holling (Eds.), Panarchy:

Understanding transformations in human and natural systems (pp.103-20). Washington DC: Island Press.

Wolfe, C. (2010). What is posthumanism? Minneapolis MN: University of Minnesota Press. 